\title{
Incidence of new foci of hepatocellular carcinoma after radiofrequency ablation: role of multidetector CT
}

\section{Incidenza di nuovi noduli di epatocarcinoma dopo termoablazione con radiofrequenza: ruolo della TC multidetettore}

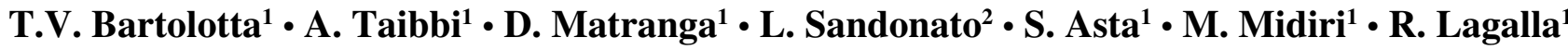 \\ ${ }^{1}$ Department of Radiology, University of Palermo, Via Del Carabiniere 32, 90127 Palermo, Italy \\ ${ }^{2}$ Department of Oncology, Division of General and Oncological Surgery, University of Palermo, Via Del Vespro 129, \\ 90127 Palermo, Italy \\ Correspondence to: T.V. Bartolotta, Tel: +39-091-6552330, Fax +39-091-6552337, e-mail: tv.bartolotta@unipa.it
}

Received: 26 February 2011 / Accepted: 31 March 2011 / Published online: 18 November 2011

C Springer-Verlag 2011

\begin{abstract}
Purpose. The authors sought to assess the incidence of new foci of hepatocellular carcinoma (HCC) using multidetector computed tomography (MDCT) in patients treated with radiofrequency ablation (RFA).

Materials and methods. Two readers retrospectively reviewed by consensus the follow-up MDCT studies of 125 patients ( 88 men and 37 women; mean age 68 years) with $141 \mathrm{HCCs}$ (size $1-5.2 \mathrm{~cm}$; mean $2.2 \mathrm{~cm}$ ) treated with RFA. MDCT follow-up was performed at 1 and 3 months and every 6-12 months thereafter. Reviewers assessed: (1) the presence of new HCC foci in the same liver segment or in a different segment; (2) complete or incomplete tumour ablation; (3) tumour progression.

Results. A total of 113 new HCCs (size $0.7-4.8 \mathrm{~cm}$; mean $1.7 \mathrm{~cm}$ ) were detected in 69/125 $(55.2 \%$ ) patients (mean follow-up $30.38 \pm 19.14$ months). Of these, 86 (76.1\%) new HCCs were multiple $(p<0.0001)$, and $92(81.4 \%)$ occurred in a different segment from that of the treated HCC $(p<0.0001)$. New HCCs were observed in the first 12 months, between 12 and 24 months and after 24 months in 31/69 (44.9\%), 24/69 (34.8\%) and 14/69 (20.3\%) patients, respectively $(p=0.175)$. Mean diseasefree interval was $16.1 \pm 16.31$ (range 1-52) months. Complete tumour ablation was achieved in 132/141 $(93.6 \%)$ treated HCCs, and tumour progression occurred in 29/141 (20.6\%) cases.

Conclusions. In patients with RFA-treated HCCs, MDCT follow-up revealed a high incidence of new HCCs, even after 1 year of follow-up. The new foci tended to be
\end{abstract}

\section{Riassunto}

Obiettivo. Scopo del lavoro è stato valutare l'incidenza di nuovi noduli di epatocarcinoma (HCC) mediante tomografia computerizzata multidetettore (TCMD) in pazienti sottoposti a termoablazione mediante radiofrequenza (RFTA).

Materiali e metodi. Due radiologi hanno valutato retrospettivamente e in consenso gli studi TCMD relativi al follow-up di 125 pazienti (88 uomini e 37 donne; età media: 68 anni) affetti da 141 HCC (dimensioni: 1-5,2 cm; media: 2,2 cm) trattati con RFTA. Il follow-up con TCMD è stato effettuato a 1, 3 ed ogni 6-12 mesi dopo I'RFTA. I due revisori hanno valutato: (1) comparsa di nuovi HCC nello stesso segmento o in segmenti differenti dall'HCC trattato; (2) trattamento completo o incompleto; (3) progressione tumorale.

Risultati. Centotredici nuovi HCC (dimensioni: 0,7-4,8 cm; media: $1,7 \mathrm{~cm}$ ) sono stati individuati in 69/125 (55,2\%) pazienti (follow-up medio: 30,38 $\pm 19,14$ mesi); $86 / 113(76.1 \%)$ nuovi HCC erano multipli $(p<0,0001)$. Novantadue/113 (81.4\%) nuovi HCCs sono stati osservati in un altro segmento rispetto all'HCC trattato $(p<0,0001)$. Trentuno/69 (44,9\%) pazienti hanno sviluppato nuovi noduli di HCC nei primi 12 mesi di follow-up, 24/69 $(34,8 \%)$ tra 12 e 24 mesi e i rimanenti $14 / 69(20,3 \%)$ oltre i 24 mesi $(p=0,175)$. L'intervallo libero da malattia è stato in media di 16,1 $\pm 16,31$ mesi (intervallo: 1-52 mesi). Sono stati osservati 132/141 (93,6\%) casi di trattamento completo e $29 / 141$ (20,6\%) casi di progressione locale del tumore. 
multiple and located in a liver segment different from that of the previously treated nodules.

Keywords Radiofrequency ablation (RFA) - Liver · CT . Liver neoplasms
Conclusioni. In pazienti sottoposti a RFTA, la TCMD rivela un'elevata incidenza di nuovi foci di HCC, già entro un anno, solitamente multipli e in segmenti diversi rispetto al nodulo trattato.

Parole chiave Termoablazione con radiofrequenza (RFTA) . Fegato $\cdot$ TC $\cdot$ Neoplasie epatiche

\section{Introduction}

Radiofrequency ablation (RFA) is increasingly being used as the percutaneous treatment of choice for patients with early-stage hepatocellular carcinoma (HCC) in whom surgical resection or liver transplantation are not feasible or available, as it guarantees excellent local control with acceptable morbidity and mortality rates [1-3]. An accurate assessment of response to treatment is essential considering that, although complete treatment significantly increases patient survival, evidence of viable tumour tissue typically represents a precise indication for repeated treatment [4]. However, regardless of the treatment strategy, HCC has a high rate of intrahepatic distant recurrence, which is associated with a significant increase in mortality rates $[5,6]$. As a consequence, early detection of new HCC nodules at follow-up is crucial to improve clinical management and, ultimately, patient survival [7]. For this purpose, diagnostic imaging, and multidetector computed tomography (MDCT) in particular, plays a key role in clinical practice $[8,9]$. The purpose of this study was to assess the incidence of new HCC foci at MDCT in patients who underwent RFA.

\section{Materials and methods}

Patients and lesions

After obtaining approval from the local ethics committee, we retrospectively studied 125 cirrhotic patients ( 88 men and 37

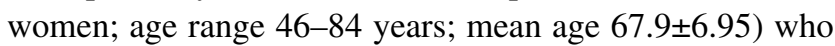
had undergone RFA treatment of $141 \mathrm{HCC}$ nodules (size $1-5.2 \mathrm{~cm}$; mean, $2.2 \pm 0.83 \mathrm{~cm}$ ) between February 1999 and March 2010. Tables 1 and 2 list patient and HCC characteristics. Inclusion criteria were the following: (1) presence of at least one HCC nodule treated with RFA; (2) availability of at least one multiphase post-RFA MDCT study in our institutional Picture Archiving and Communication System (PACS) (Impax, Agfa-Gevaert, Milan, Italy).

RFA technique

All treatments were performed using the ultrasound (US)-

\section{Introduzione}

La termoablazione mediante radiofrequenza (RFTA) è sempre più frequentemente impiegata come trattamento percutaneo di scelta per quei pazienti affetti da epatocarcinoma (HCC) in stadio precoce, allorquando la resezione chirurgica o il trapianto di fegato sono opzioni non praticabili o non disponibili, garantendo un eccellente controllo locale di malattia a fronte di accettabili tassi di morbilità e mortalità [1-3]. Un'accurata valutazione della risposta terapeutica è di cruciale importanza, considerato che, mentre un trattamento completo migliora significativamente la sopravvivenza dei pazienti, l'identificazione di tessuto tumorale vitale pone, di norma, la precisa indicazione ad un nuovo trattamento [4]. Tuttavia, indipendentemente dalla modalità di trattamento, l'epatocarcinoma presenta un elevato tasso di recidiva intraepatica a distanza, quest'ultimo associato ad un significativo incremento della mortalità [5, 6]. Di conseguenza, la precoce individuazione di nuovi noduli di HCC durante il follow-up risulta fondamentale al fine di migliorare la gestione clinica del paziente e, in ultima analisi, la sopravvivenza [7]. A tale scopo, nella pratica clinica, le tecniche di diagnostica per immagini, e tra queste la tomografia computerizzata multidetettore (TCMD), giocano un ruolo chiave [8, 9]. Scopo del presente lavoro è stato quello di valutare l'incidenza di nuovi foci di HCC alla TCMD in pazienti sottoposti a trattamento di RFTA di epatocarcinoma.

\section{Materiali e metodi}

Pazienti e lesioni

Ottenuta l'approvazione da parte del comitato etico istituzionale, sono stati retrospettivamente valutati 125 pazienti (88 uomini; 37 donne) di età compresa fra 46 e 84 anni (età

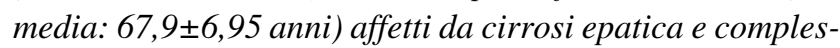
sivamente sottoposti a trattamento di RFTA di 141 noduli di HCC (dimensioni: $1-5,2 \mathrm{~cm}$; media 2,2 $\pm 0,83 \mathrm{~cm}$ ) dal febbraio 1999 al marzo 2010. Le Tabelle 1 e 2 mostrano in dettaglio, rispettivamente, le caratteristiche dei pazienti e degli epatocarcinomi inclusi nello studio. In particolare, i criteri 
di inclusione nello studio sono stati: (1) presenza di almeno un nodulo di HCC sottoposto a RFTA; (2) disponibilità di almeno uno studio TCMD multifasico post-RFTA reperito nel nostro PACS istituzionale (Impax, Agfa-Gevaert, Milano, Italia).

\section{Tecnica RFTA}

Tutti i trattamenti sono stati effettuati con tecnica percutanea ( $n=97)$, laparoscopica $(n=7)$ o chirurgica open $(n=37)$ mediante guida ecografica ed impiegando gli aghi e $i$ generatori indicati in Tabella 3. L'ago-elettrodo è stato posizionato al centro della lesione e la temperatura della sua estremità è stata mantenuta a $100^{\circ} \mathrm{C}$ per circa $10-12$ minuti. Dopo la termoablazione, l'ago è stato estratto mantenendo l'estremità calda al fine di prevenire, mediante termocoagulazione, eventuali fenomeni emorragici o un accidentale insemenzamento neoplastico lungo il percorso dell'ago.

Tecnica d'esame TC e follow-up

I pazienti sono stati sottoposti ad esame TC dopo un mese dal trattamento e, qualora negativo, a distanza di 3 e poi 6-12 mesi, salvo diversa indicazione clinica o esigenze relative al paziente. Lo studio TC è stato eseguito utilizzando un'apparecchiatura multidetettore a 64 strati Philips Brilliance (Royal Philips Electronics, Andover MA, USA) acquisendo immagini in condizioni di base e dopo somministrazione di $1,5 \mathrm{ml} / \mathrm{kg}$ di iomeprolo $(400 \mathrm{mgI} / \mathrm{ml}$; Iomeron Bracco, Milano, Italia) ad una velocità di $4 \mathrm{ml} / \mathrm{s}$ mediante un iniettore automatico. L'esame è stato eseguito con tecnica multifasica, utilizzando il bolus tracking. Una regione di interesse (ROI) è stata posizionata in corrispondenza dell'aorta addominale a livello del tripode celiaco ed è stata selezionata una soglia di $150 \mathrm{UH}$. Una volta raggiunta quest'ultima sono state effettuate tre scansioni impostando un ritardo, rispettivamente, di 20-25 s (fase arteriosa), $50 \mathrm{~s}$ (fase portale-venosa) e 180-300 s (fase all'equilibrio).

Analisi delle immagini

Per la valutazione delle immagini TCMD, è stato impiegato il sistema picture archiving and communications system (PACS) in dotazione alla nostra istituzione (Impax, AgfaGevaert, Milano, Italia). Due radiologi con più di dieci anni di esperienza in radiologia addominale, non coinvolti nell'esecuzione degli esami e non a conoscenza della storia clinica dei pazienti né della diagnosi finale, hanno esaminato in consenso off-line le immagini ottenute. I due osservatori hanno esaminato le immagini per individuare l'insorgenza di nuove lesioni e valutare l'esito del trattamento. La sede delle lesioni è stata stabilita in accordo con la classificazione di Couinaud. In particolare è stata valutata: 
Table 2 Characteristics of 141 hepatocellular carcinomas treated with radiofrequency ablation

\begin{tabular}{llllll}
\hline Nodules treated & $\begin{array}{l}\text { Mean diameter } \\
\text { (interval) }\end{array}$ & $\begin{array}{l}\text { Histopathological } \\
\text { diagnosis }\end{array}$ & $\begin{array}{l}\text { Clinical and radiological } \\
\text { diagnosis }\end{array}$ & $\begin{array}{l}\text { Solitary } \\
\text { tumours }^{\mathrm{a}}\end{array}$ & $\begin{array}{l}\text { Multiple } \\
\text { tumours }^{\mathrm{a}}\end{array}$ \\
\hline 141 & $2.2 \mathrm{~cm}(0.5-5.2 \mathrm{~cm})$ & $28(25$ patients $)$ & $113(100$ patients $)$ & $111(111$ patients $)$ & $30(14$ patients $)$ \\
\hline
\end{tabular}

at the time of radiofrequency ablation

Tabella 2 Caratteristiche dei 141 HCC trattati con RFTA

\begin{tabular}{lllll}
\hline Noduli trattati & $\begin{array}{l}\text { Diametro medio } \\
\text { (intervallo) }\end{array}$ & $\begin{array}{l}\text { Diagnosi } \\
\text { istopatologica }\end{array}$ & $\begin{array}{l}\text { Diagnosi } \\
\text { clinico-radiologica }^{\text {Tumori }}\end{array}$ & $\begin{array}{l}\text { Tumori } \\
\text { singoli }\end{array}$ \\
\hline 141 & $2,2 \mathrm{~cm}(0,5-5,2 \mathrm{~cm})$ & $28(25$ pazienti) & $113(100$ pazienti) & $111(111$ pazienti) \\
\hline
\end{tabular}

${ }^{a}$ al momento del trattamento di RFTA

guided percutaneous technique $(n=97)$, laparoscopy $(n=7)$ or open surgery $(n=37)$ with needles and generators indicated in Table 3. The needle electrode was positioned at the centre of the lesion, and the temperature at its tip was kept at $100^{\circ} \mathrm{C}$ for $10-12 \mathrm{~min}$ approximately. After thermal ablation, the needle was withdrawn while the tip was kept warm to prevent, through thermal coagulation, any bleeding or accidental needle-track seeding.

CT examination and follow-up

Patients underwent CT examination 1 month after treatment and, if results were negative, at 3 and then 6-12 months, unless there were specific clinical indications or patient requirement. CT studies were obtained with a 64-slice Philips Brilliance scanner (Royal Philips Electronics, Andover MA, USA). Images were acquired at baseline and after administration of $1.5 \mathrm{ml} / \mathrm{kg}$ of iomeprol $(400 \mathrm{mgI} / \mathrm{ml}$ ) (Iomeron, Bracco, Milan, Italy) delivered at a flow rate of $4 \mathrm{ml} / \mathrm{s}$ using an automatic injector. Scans were performed using the mul-
1. l'insorgenza di nuovi foci di HCC, definiti come noduli ipervascolari in fase arteriosa e con wash-out in fase portale elo all'equilibrio insorgenti in altro segmento rispetto al nodulo trattato con RFTA o nello stesso segmento, ma ad una distanza superiore a $2 \mathrm{~cm}$ dal nodulo trattato [10];

2. la presenza di foci di ipervascolarità nodulare ad una distanza inferiore a $2 \mathrm{~cm}$ dal nodulo inizialmente trattato è stata considerata: (a) tumore residuo non ablato (persistenza di malattia) se rilevata al primo controllo TC post-RFTA (1 mese dopo il trattamento);(b) progressione locale del tumore (ripresa di malattia) se rilevata ad un successivo controllo TC (in questi casi nel controllo ad 1 mese era assente tessuto tumorale residuo).

\section{Standard di riferimento}

La diagnosi definitiva relativa ai 113 nuovi noduli di HCC è stata ottenuta, oltre che mediante TCMD, anche mediante altre tecniche di diagnostica per immagini quali risonanza

Table 3 Radiofrequency ablation technique

\begin{tabular}{lllll}
\hline Generator & $50 \mathrm{~W}(4$ needles $)$ & $50 \mathrm{~W}(7$ needles $)$ & $150 \mathrm{~W}(7$ needles $)$ & $150 \mathrm{~W}(9$ needles $)$ \\
\hline Nodules treated & $2(\mathrm{P})$ & $10(\mathrm{P})$ & $11(\mathrm{P})$ & $74(\mathrm{P})$ \\
& $3(\mathrm{O})$ & $7(\mathrm{O})$ & $3(\mathrm{O})$ & $24(\mathrm{O})$ \\
Total & 5 & 17 & 14 & $7(\mathrm{~L})$ \\
\end{tabular}

$P$, percutaneous; $O$, open surgery; $L$, laparoscopy

Tabella 3 Tecnica RFTA

\begin{tabular}{lllll}
\hline Generatore & $50 \mathrm{~W}(4$ uncini $)$ & $50 \mathrm{~W}(7$ uncini $)$ & $150 \mathrm{~W}(7$ uncini $)$ & $150 \mathrm{~W}(9$ uncini $)$ \\
\hline Noduli trattati & $2(P)$ & $10(P)$ & $11(P)$ & $74(P)$ \\
& $3(O)$ & $7(O)$ & $3(O)$ & $24(O)$ \\
Totale & 5 & 17 & 14 & 105 \\
\hline
\end{tabular}

$P$, percutanea; $O$, open; L, laparoscopica 
tiphase bolus tracking technique. A region of interest (ROI) was positioned near the abdominal aorta, at the level of the celiac tripod, and an enhancement threshold of $150 \mathrm{HU}$ was selected. Once the threshold was reached, three scans were obtained with a delay of 20-25 s (arterial phase), $50 \mathrm{~s}$ (portal-venous phase) and 180-300 s (equilibrium phase).

Image analysis

Image analysis was conducted on our institution's PACS system (Impax, Agfa-Gevaert, Milan, Italy). Two radiologists with $>10$ years of experience in abdominal radiology, not involved in the scanning phase and blinded to patients' clinical history and final diagnoses reviewed the images in consensus working off-line. Images were assessed for the development of new lesions and response to treatment. Lesion site was identified following the Couinaud classification. In particular, the readers assessed:

1. The development of new HCC foci, defined as hypervascular nodules in the arterial phase and with washout in the portal and/or equilibrium phase, arising in either a different segment from that of the RFA-treated nodule or in the same segment but at a distance $>2 \mathrm{~cm}$ from the treated nodule [10];

2. The presence of foci of nodular hypervascularity $<2 \mathrm{~cm}$ from the nodule treated initially was considered: (a) residual, nonablated tumour (disease persistence) if detected at the first follow-up CT after RFA (1 month after treatment), and (b) local tumour progression (disease relapse) if detected at subsequent follow-up CT scans (in these cases, no residual neoplastic tissue was evident at 1-month follow-up).

Standard of reference

Definite diagnosis of the 113 new HCC nodules was obtained by MDCT and other imaging modalities, such as magnetic resonance (MR) imaging with liver-specific contrast agent $(n=97)$ and/or contrast-enhanced US $(n=85)$, according to imaging criteria recognised by international guidelines [11].

Statistical analysis

With regard to the development of new HCC nodules after RFA, the following potential risk factors were analysed: (a) advanced stage of underlying liver disease (Child-Pugh class C); (b) treated tumour with maximum diameter $>2 \mathrm{~cm}$; (c) previous interventional or surgical treatment; (d) multiple tumour at the time of RFA treatment; (e) contact between the treated tumour and the major hepatic vessels; (f) contact between the treated tumour and the hepatic capsule; (g) inadequate resection margins.

Statistical analysis was carried out with a commercial programme (Intercooled Stata, version 9.2 for Windows, magnetica (RM) con mezzo di contrasto $(M d C)$ epatospecifico ( $n=97)$ elo ecografia con $M d C(n=85)$ secondo i criteri semeiologici riconosciuti dalle linee guida internazionali [11].

\section{Analisi statistica}

Relativamente alla comparsa di nuovi noduli di HCC dopo RFTA sono stati valutati $i$ seguenti potenziali fattori di rischio: (a) grado avanzato della sottostante malattia epatica (classe Child-Pugh C); (b) diametro massimo del tumore trattato superiore a $2 \mathrm{~cm}$; (c) pregresso trattamento interventistico o chirurgico; (d) tumore multiplo al momento della RFTA; (e) contatto del tumore trattato con $i$ vasi epatici maggiori; $(f)$ contatto del tumore trattato con la capsula epatica; $(g)$ inadeguatezza dei margini di resezione.

L'analisi statistica è stata effettuata mediante un programma commerciale (Intercooled Stata, versione 9.2 per Windows, StateCorp, TX, USA), mediante il test del chiquadrato, o il test esatto di Fisher quando appropriato, con livello di significatività statistica fissato a $p$ inferiore a 0,05 .

\section{Risultati}

Complessivamente, $i 125$ pazienti studiati sono stati controllati mediante TCMD per un periodo mediamente pari a 23,78 $\pm 20,48$ mesi (intervallo: 1-89 mesi).

Nuovi noduli di HCC

Centotredici nuovi foci di HCC (dimensioni: 0,7-4,8 cm; media: 1,7 $\pm 0,72 \mathrm{~cm})$ sono stati individuati alla TCMD in $69 / 125(55,2 \%)$ pazienti, monitorati in media per 30,38 $\pm 19,14$ mesi (intervallo: 1-89 mesi) (Fig. 1). Ottantasei nuovi noduli di HCC su 113 (76,1\%) erano multipli, mentre i rimanenti $27 / 113(23,9 \%)$ nuovi noduli erano singoli $(p<0,0001)$. In particolare, 7 pazienti hanno sviluppato 2 noduli, 10 pazienti 3 noduli, 4 pazienti 4 noduli e i rimanenti 4 pazienti 5, 6, 7 e 8 noduli ciascuno.

L'intervallo libero da malattia è stato in media di 16,1 16,31 mesi (intervallo: 1-52 mesi). In particolare, $31 / 69$ (44,9\%) pazienti hanno sviluppato nuovi noduli di HCC nei primi 12 mesi di follow-up, $24 / 69$ (34,8\%) pazienti tra 12 e 24 mesi e i rimanenti $14 / 69$ (20,3\%) oltre i 24 mesi $(p=0,175)$. Per quanto attiene la sede dei nuovi noduli rispetto al primitivo nodulo trattato mediante RFTA, $21 / 113(18,6 \%)$ HCC sono insorti nello stesso segmento mentre la maggioranza dei nuovi foci di HCC $(92 / 113 ; 81,4 \%)$ si è sviluppata in altri segmenti epatici $(p<0,0001)$, prevalentemente nel lobo destro (70/113; 
StateCorp, TX, USA) using the chi-square test, or the Fisher exact test when appropriate, with statistical significance set at $p<0.05$.

\section{Results}

Overall, the 125 patients were followed up by MDCT for a mean period of $23.78 \pm 20.48$ (range $1-89$ ) months.

New HCC nodules

A total of 113 new HCC foci $(0.7-4.8 \mathrm{~cm}$; mean $1.7 \pm 0.72$ $\mathrm{cm})$ were identified at MDCT in 69/125 (55.2\%) patients followed up for an average of 30.38 19.14 (range 1-89) months (Fig. 1). Of these new nodules, 86 (76.1\%) were multiple and the remaining $27(23.9 \%)$ were solitary $(p<0.0001)$. In particular, seven patients developed two nodules, ten three nodules, four four nodules and the remaining four five, six, seven and eight nodules each.

Mean disease-free interval was $16.1 \pm 16.31$ (range 1-52) months. In particular, 31/69 (44.9\%) patients developed new HCC nodules during the first 12 months of follow-up, $24 / 69(34.8 \%)$ from 12 to 24 months and the remaining 14 $(20.3 \%)>24$ months after treatment $(p=0.175)$. Regarding the site of the new HCC relative to the treated nodule, 21/113 (18.6\%) occurred in the same segment, whereas the majority of new HCC foci $(92 / 113 ; 81.4 \%)$ occurred in other hepatic segments $(p<0.0001)$, more frequently in the right $(70 / 113$; $62 \%)$ than in the left $(43 / 113 ; 38 \%)$ lobe $(p=0.0003)$ (Table 4). Fifty-six of 125 patients $(44.8 \%)$ did not develop new $\mathrm{HCC}$ foci. These patients were followed up for an average of $15.64 \pm 19.25$ (range 1-89) months, that is, for a significantly shorter period compared with the 69 patients with new HCC nodules $(30.38 \pm 19.14$ months $)(p<0.001)$. The only risk fac-
$62 \%)$ rispetto al sinistro $(43 / 113 ; 38 \%)(p=0,0003)(\mathrm{Ta}$ bella 4). Cinquantasei pazienti su 125 (44,8\%) non hanno sviluppato nuovi foci di HCC. Questi pazienti sono stati monitorati in media 15,64 19,25 mesi (intervallo: 1-89 mesi), periodo mediamente inferiore in maniera statisticamente significativa rispetto ai 69 pazienti con nuovi noduli di HCC (30,38 $\pm 19,14$ mesi) ( $p<0,001)$. L'unico fattore di rischio che ha presentato una correlazione statisticamente significativa con l'insorgenza di nuovi noduli di HCC è risultato essere la vicinanza alla capsula epatica $(p<0,018)$ (Tabella 5).

Persistenza di malattia e/o progressione locale

Complessivamente, sono stati osservati 9/141 (6,4\%) casi di trattamento incompleto a fronte di una necrosi completa nei rimanenti 132/141 (93,6\%) noduli trattati ( $p<0,0001)$. La progressione locale del tumore è stata osservata in 29/141 (20,6\%) casi, dopo un intervallo di tempo pari a 2-48 mesi (media: 13,2 mesi). In particolare, 16/29 (55\%) casi si progressione sono stati riscontrati entro i primi 12 mesi dal trattamento, 10/29 (35\%) fra 12 e 36 mesi dopo il primo trattamento e 3/29 (10\%) dopo 36 mesi $(p=0,067)$. Nessuna recidiva locale è stata osservata dopo 48 mesi e l'intervallo libero da recidiva è risultato in media di 15,64士19,25 mesi (intervallo: 2-38 mesi).

\section{Discussione}

Nella nostra serie di pazienti, trattati mediante RFTA e controllati con TCMD in media per circa due anni, nuovi noduli di HCC sono stati riscontrati in poco più della metà dei casi (55,2\%). L'alto tasso di nuovi tumori rilevati è
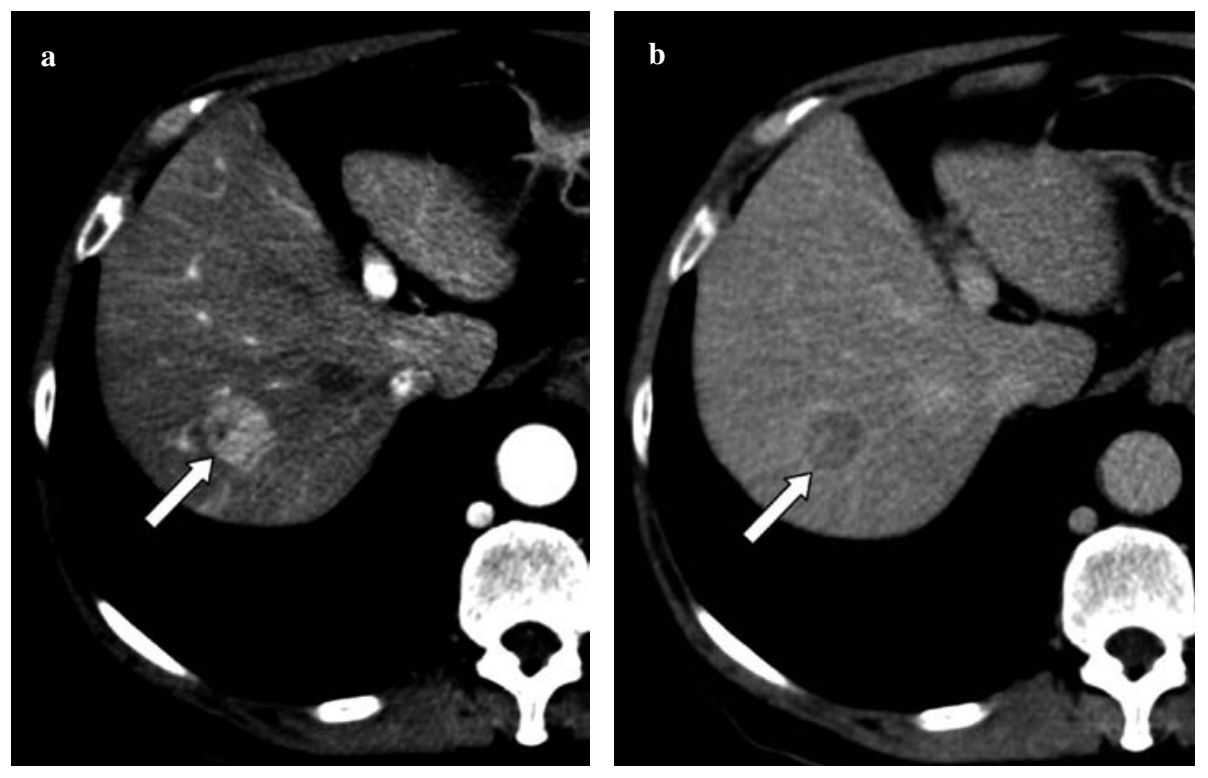

Fig. 1a,b New focus of hepatocellular carcinoma in a 57-year-old man. a At 18-month computed tomography after radiofrequency ablation, a roundish hyperattenuating mass of $2.1 \mathrm{~cm}$ is appreciable in segments VI-VII during the arterial phase (arrow); b during the portal-venous phase, the lesion shows a clearcut washout with a peripheral hyperattenuating rim (arrow).

Fig. 1a,b Nuovo nodulo di epatocarcinoma in uomo di 57 anni. a Alla TC effettuata 18 mesi dopo RFTA, in corrispondenza del VIVII segmento, si apprezza una formazione ovalare iperdensa in fase arteriosa del diametro di $2,1 \mathrm{~cm}$ (freccia). $\boldsymbol{b}$ In fase portale, la lesione mostra evidente wash-out ed appare delimitata da sottile cercine iperdenso (freccia). 
Table 4 Number and location of new hepatocellular carcinoma nodules

\begin{tabular}{ll}
\hline Hepatic segment & New nodules (n) \\
\hline I & 3 \\
II & 14 \\
III & 8 \\
IV & 18 \\
V & 12 \\
VI & 18 \\
VII & 17 \\
VIII & 23 \\
\hline
\end{tabular}

tor found to correlated significantly with the development of new HCC nodules was proximity to the hepatic capsule $(p<0.018)$ (Table 5).

Disease persistence and/or local progression

Incomplete treatment was seen in 9/141 (6.4\%) cases and complete necrosis in the remaining $132(93.6 \%)$ treated nodules $(p<0.0001)$. Local tumour progression was seen in $29(20.6 \%)$ cases after a time interval of $2-48$ (mean 13.2) months. In particular, $16 / 29(55 \%)$ cases of progression were observed within the first 12 months after treatment, 10 (35\%) between 12 and 36 months after initial treatment and $3(10 \%)$ after 36 months $(p=0.067)$. No local relapse was observed after 48 months, and the relapse-free interval was $15.64 \pm 19.25$ months on average (range $2-38$ months).

\section{Discussion}

In our series of patients treated with RFA and followed up by MDCT for an average of 2 years, new HCC nodules were identified in slightly more than half of the cases (55.2\%). The high rate of new tumours reflects the intrinsic multicentric nature of HCC that develops in the cirrhotic liver and does not represent a drawback of RFA. In fact, similar recurrence rates may be observed in cirrhotic patients with HCC treated with any type of percutaneous technique or even after surgical resection [12]. Although in our experience new HCC nodules were detected in significant percentages of cases as late as 2 and 3 years after treatment (in 35\% and $20 \%$ of cases, respectively), most patients (45\% approximately) developed new HCC foci within 1 year from treatment. Although not statistically significant, this finding may be related to data reported by Park et al. concerning a more rapid growth rate of new HCC nodules in patients treated with RFA compared with nontreated HCC, suggesting the need for shorter follow-up intervals in the first group compared with the second [13]. However, it should be noted that the group of patients who did not develop new HCC nodules in our series had a substantially shorter follow-up period,
Tabella 4 Numero di nuovi noduli di HCC e loro sede

\begin{tabular}{ll}
\hline Segmento epatico & Nuovi noduli $(n)$ \\
\hline$I$ & 3 \\
$I I$ & 14 \\
$I I I$ & 8 \\
IV & 18 \\
$V$ & 12 \\
VI & 18 \\
VII & 17 \\
VIII & 23 \\
\hline
\end{tabular}

espressione dell'intrinseca natura multicentrica dell'HCC insorgente nel fegato cirrotico e, dunque, non rappresenta un inconveniente dell'RFTA. Un analogo tasso di recidiva si può riscontrare, infatti, in pazienti cirrotici con HCC che sono trattati con qualsiasi tipo di terapia percutanea o, anche, dopo resezione chirurgica [12]. Sebbene nella nostra esperienza nuovi noduli di HCC siano stati riscontrati in percentuali significative anche dopo due e tre anni dal trattamento - rispettivamente nel $35 \%$ e nel $20 \%$ dei casi - la maggioranza dei pazienti trattati ha sviluppato nuovi foci di HCC nell'arco del primo anno di controlli, con una percentuale di circa il $45 \%$. Anche se privi di significatività statistica, tali reperti possono essere messi in relazione con il dato riportato da Park et al. [13] di un più rapido tasso di crescita di nuovi noduli di epatocarcinoma in pazienti trattati con RFTA rispetto agli epatocarcinomi non trattati, suggerendo nei primi l'effettuazione di controlli più ravvicinati nel tempo rispetto ai secondi [13]. Tuttavia, è opportuno sottolineare come, nella nostra serie, il gruppo dei pazienti che non ha sviluppato nuovi HCC sia stato monitorato per un tempo nettamente inferiore, pari a circa la metà, rispetto al primo. Ne consegue, anche in considerazione dell'elevato tasso di nuovi foci di HCC riportato da Lencioni et al. [12] al prolungarsi del follow-up, pari a ben l'81\% a cinque anni, che il perdurare dell'osservazione avrebbe potuto condurre alla scoperta di nuovi noduli anche in questo gruppo di pazienti [12].

I nuovi foci di HCC da noi osservati si sono manifestati in maniera statisticamente significativa prevalentemente in forma multipla $(86 / 113 ; 76,1 \%)$ ed in segmenti epatici diversi $(92 / 113 ; 81,4 \%)$ rispetto alla sede del primitivo nodulo di HCC trattato mediante RFTA. In particolare, sebbene nella nostra casistica i segmenti maggiormente coinvolti dall'insorgenza di nuovi noduli siano stati quelli di destrarispettivamente l'VIII, seguito dal VII e dal VI-nessun segmento è stato tuttavia risparmiato. Tali rilievi sono sostanzialmente in accordo con $i$ dati di letteratura che indicano un elevato tasso di recidiva intraepatica dell'HCC in siti diversi rispetto a dove è avvenuto il trattamento termoablativo, con percentuali variabili dal 40,6\% al 53\% [2, 6, 14 , 15]. A tale proposito, vi è evidenza che la recidiva in un di- 
Table 5 Potential risk factors for the development of new hepatocellular carcinoma foci in 125 patients

\begin{tabular}{|c|c|c|c|c|c|}
\hline \multirow[t]{2}{*}{ Risk factor } & \multicolumn{2}{|c|}{ Patients with new nodules $(n=69)$} & \multicolumn{2}{|c|}{ Patients with no new nodules $(n=56)$} & \multirow[t]{2}{*}{$p$ value $^{a}$} \\
\hline & Present & Absent & Present & Absent & \\
\hline Advanced-stage liver disease & 2 & 67 & 0 & 56 & 0.501 \\
\hline Multiple tumour & 10 & 59 & 4 & 52 & 0.258 \\
\hline Treated tumour diameter $>2 \mathrm{~cm}$ & 40 & 29 & 25 & 31 & 0.153 \\
\hline Previous interventional treatment & 11 & 58 & 4 & 52 & 0.171 \\
\hline Contact with major hepatic vessels & 4 & 65 & 1 & 55 & 0.379 \\
\hline Contact with hepatic capsule & 14 & 55 & 3 & 53 & 0.018 \\
\hline Inadequate resection margins & 4 & 65 & 5 & 51 & 0.513 \\
\hline
\end{tabular}

${ }^{a}$ Chi-square or Fisher exact test (significance $p<0.05$ )

Tabella 5 Potenziali fattori di rischio per la comparsa di nuovi noduli di HCC in 125 pazienti

\begin{tabular}{|c|c|c|c|c|c|}
\hline \multirow[t]{2}{*}{ Fattore di rischio } & \multicolumn{2}{|c|}{ Pazienti con nuovi noduli $(n=69)$} & \multicolumn{2}{|c|}{ Pazienti senza nuovi noduli $(n=56)$} & \multirow[t]{2}{*}{$p^{a}$} \\
\hline & Presente & Assente & Presente & Assente & \\
\hline Grado avanzato malattia epatica & 2 & 67 & 0 & 56 & 0,501 \\
\hline Tumore multiplo & 10 & 59 & 4 & 52 & 0,258 \\
\hline Diametro del tumore trattato $>2 \mathrm{~cm}$ & 40 & 29 & 25 & 31 & 0,153 \\
\hline Pregresso trattamento interventistico & 11 & 58 & 4 & 52 & 0,171 \\
\hline Contatto con i vasi epatici maggiori & 4 & 65 & 1 & 55 & 0,379 \\
\hline Contatto con la capsula epatica & 14 & 55 & 3 & 53 & 0,018 \\
\hline Margini di resezione inadeguati & 4 & 65 & 5 & 51 & 0,513 \\
\hline
\end{tabular}

${ }^{a}$ test chi-quadrato o test esatto di Fisher (significatività: $p<0,05$ )

almost half of the first group. As a consequence, and in view of the high rate of new HCC foci reported by Lencioni et al. over longer follow-up periods (as high as $81 \%$ at 5 years), a longer follow-up period might have led to detection of new nodules in this group of patients [12].

There was a statistically significant predominance of new HCC foci that were multiple $(86 / 113 ; 76.1 \%)$ and occurring in different segments $(92 / 113 ; 81.4 \%)$ relative to the site of the primary HCC nodule treated with RFA. In particular, although in our series the segments most commonly involved by the new nodules were the right-side segments, i.e. segments VIII, VII and VI, no segments were spared. These findings are consistent with the literature, which indicates a high rate of intrahepatic HCC recurrence at sites other than that of the RFA, with percentages ranging from $40.6 \%$ to $53 \%[2,6,14,15]$. In this respect, there is evidence that recurrence in a different hepatic segment, associated with the presence of distant metastases, has a significant negative influence on overall survival; hence, constant monitoring and aggressive treatment may be indicated in patients with intrahepatic recurrence in a different segment in order to optimise the benefits of RFA $[6,7]$. Therefore, all the above confirms the advantage of following up patients treated with RFA with an imaging modality, such as MDCT, which is able to visualise the entire hepatic parenchyma. Other modalities, such as contrast-enhanced US, may be useful for assessing treatment effectiveness - verso segmento epatico, insieme alla presenza di metastasi a distanza, influenzano negativamente e significativamente la sopravvivenza globale, per cui una sorveglianza regolare e un trattamento aggressivo possono risultare indicati in pazienti con recidiva intraepatica in un segmento differente per ottimizzare i benefici dell'RFTA [6, 7]. Quanto sopra riportato conferma, quindi, tutta l'importanza ed il vantaggio di impiegare ai fini del monitoraggio dei pazienti sottoposti a RFTA una tecnica, quale la TCMD, in grado di valutare l'intero parenchima epatico. Infatti altre tecniche, quali ad esempio l'ecografia con mezzo di contrasto, possono essere sicuramente utili per valutare l'efficacia del trattamento, soprattutto durante la procedura interventistica stessa, ma risultano poco o affatto indicate nella individuazione di nuovi foci di epatocarcinoma nei successivi controlli [16, 17].

Meno univoci sono i dati riportati in letteratura riguardo i fattori di rischio della recidiva intraepatica a distanza dell'HCC. Nello studio di Zytoon et al. [18], ad esempio, non è stato rilevato alcun significativo fattore di rischio. Di contro, nello studio di Yamanaka et al. [15] si è giunti alla conclusione che i pazienti che hanno più noduli di HCC, bassi livelli sierici di piastrine o di albumina, associati ad infezione da virus dell'epatite $C$ dovrebbero essere seguiti attentamente a causa dell'elevata incidenza di nuove lesioni di HCC nel resto del fegato, anche dopo necrosi coagulativa 
especially during the interventional procedure - but they have few or no indications for detecting new HCC foci during the follow-up [16, 17].

Data regarding risk factors for intrahepatic distant recurrence of HCC are more equivocal. A study by Zytoon et al., for example, found no significant risk factor [18]. Conversely, Yamanaka et al. reached the conclusion that patients with a greater number of HCC nodules, low serum platelet or albumin levels and associated $\mathrm{C}$ virus infection should undergo close monitoring because of the high incidence of new HCC lesions in the rest of the liver, even after complete post-RFA coagulative necrosis [15]. Kim et al. reported that elevated serum alpha-fetoprotein was the only risk factor for intrahepatic distant recurrence [14]. In our experience, the only risk factor that correlated significantly with the development of new HCC nodules - although difficult to ascribe to a precise pathogenetic mechanism - was proximity to the hepatic capsule. Further studies are needed to provide accurate evaluation of this statistical result.

The percentage of complete tumour ablation, assessed at MDCT, was $93.6 \%$ of the nodules (132 of 141 treated nodules). This finding is in line with previously reported values, which confirms the effectiveness of RFA in well-selected patients and suggests its use as a first-line strategy to treat patients with early-stage HCC [2, 6, 19]. During the follow-up, local tumour progression was observed in 29 cases (23.2\% of all treated patients), with a time interval ranging from 2 to 48 (mean 13.2) months. No local recurrence was observed after 48 months. These data are also in keeping with those reported in the literature $[13,18,20,21]$.

Our study has some limitations. First, the reference standard was not liver biopsy in all cases but MDCT and/or MR imaging criteria, which are, however, well established in the literature and commonly used in clinical practice. RFA was not always performed with the same equipment owing to technological improvements over the years; this, however, might have influenced failure or progression rates but not the number of new HCC nodules. Another limitation is that the readers analysed the images in consensus, so we were unable to assess the degree of agreement between independent readers.

In conclusion, in our experience, patients with HCC treated with RFA very frequently develop new nodules, even during the first year after treatment. The nodules tend to be multiple and to involve different segments relative to the treated nodule. Therefore, the use of MDCT is not only indicated for assessing treatment effectiveness in terms of disease persistence and/or recurrence but, also and above all, for detecting possible new HCC foci and allowing appropriate early treatment. completa post-RFTA [15]. Nello studio di Kim et al. [14], invece, solo l'aumento nei livelli sierici di alfa-fetoproteina (AFP) è risultato essere un fattore di rischio per la recidiva intraepatica [14]. Nella nostra esperienza, l'unico fattore di rischio correlato in maniera statisticamente significativa all'insorgenza di nuovi noduli di HCC, anche se difficilmente riconducibile ad un preciso meccanismo patogenetico, è risultato essere la vicinanza alla capsula epatica. Ulteriori studi si rendono necessari per valutare correttamente tale dato statistico.

Di contro, la percentuale di ablazione tumorale completa, individuata sulla base dell'esame TCMD, è stata del 93,6\% dei noduli (132 noduli su 141 trattati). Questo dato è sostanzialmente in linea con $i$ valori riportati in letteratura, confermando l'efficacia dell'RFTA proprio in pazienti adeguatamente selezionati e suggerendone l'impiego come tecnica di prima linea nel trattamento dei pazienti con HCC in stadio precoce [2, 6, 19]. Durante il follow-up, è stata osservata la progressione locale del tumore in 29 casi $(23,2 \%$ di tutti i pazienti trattati), con un intervallo di tempo compreso tra 2 e 48 mesi, in media 13,2 mesi. Nessuna recidiva locale è stata osservata dopo 48 mesi. Anche tali dati sono sostanzialmente in linea con quelli riportati in letteratura [13, 18, 20, 21].

Il nostro studio presenta delle limitazioni. In primo luogo lo standard di riferimento non è stato, in tutti i casi, la biopsia epatica, bensì i criteri semeiologici alla TCMD elo alla $R M$, ancorché noti in letteratura e comunemente impiegati nella pratica clinica. La tecnica RFTA non è stata eseguita con le stesse apparecchiature a causa dei miglioramenti tecnologici apportati nel tempo, ma ciò potrebbe avere avuto influenza sul tasso di insuccesso o di progressione, non di nuovi noduli di HCC. Inoltre, da parte dei lettori è stata effettuata una valutazione in consenso e, pertanto, non è stato possibile valutare il grado di correlazione tra lettori indipendenti.

In conclusione, nella nostra esperienza, i pazienti con epatocarcinomi trattati mediante RFTA sviluppano con elevata frequenza nuovi noduli di epatocarcinoma, anche durante il primo anno post-trattamento, solitamente multipli ed in segmenti differenti rispetto al nodulo trattato. L'impiego della TCMD, quindi, è indicato non solo al fine di valutare l'efficacia del trattamento, in termini di persistenza elo recidiva di malattia tumorale, ma anche e soprattutto perché tecnica in grado di rivelare adeguatamente nuovi eventuali foci di epatocarcinomi, così da consentire un adeguato e tempestivo trattamento dei pazienti.

\section{Conflict of interest None}




\section{References/Bibliografia}

1. Lencioni R, Cioni D, Crocetti L et al (2005) Early-stage hepatocellular carcinoma in patients with cirrhosis: long-term results of percutaneous image-guided radiofrequency ablation. Radiology 234:961-967

2. Choi D, Lim HK, Rhim $\mathrm{H}$ et al (2007) Percutaneous radiofrequency ablation for early-stage hepatocellular carcinoma as a first-line treatment: long-term results and prognostic factors in a large single-institution series. Eur Radiol 17:684-692

3. Ferrari FS, Megliola A, Scorzelli A et al (2007) Treatment of small HCC through radiofrequency ablation and laser ablation. Comparison of techniques and long-term results. Radiol Med 112:377-393

4. Lencioni R, Cioni D, Bartolozzi C (2001) Percutaneous radiofrequency thermal ablation of liver malignancies: techniques, indications, imaging findings, and clinical results. Abdom Imaging 26:345-360

5. Okuwaki Y, Nakazawa T, Shibuya A et al (2008) Intrahepatic distant recurrence after radiofrequency ablation for a single small hepatocellular carcinoma: risk factors and patterns. $\mathbf{J}$ Gastroenterol 43:71-78

6. Ng KK, Poon RT, Lo CM et al (2008) Analysis of recurrence pattern and its influence on survival outcome after radiofrequency ablation of hepatocellular carcinoma. J Gastrointest Surg 121:183-191

7. Okuwaki Y, Nakazawa T, Kokubu S et al (2009) Repeat radiofrequency ablation provides survival benefit in patients with intrahepatic distant recurrence of hepatocellular carcinoma. Am J Gastroenterol 104:2747-2753
8. Limanond P, Zimmerman P, Raman SS et al (2003) Interpretation of CT and MRI after radiofrequency ablation of hepatic malignancies. AJR Am J Roentgenol 181:1635-1640

9. Pozzi Mucelli MR, Como G, Del Frate $\mathrm{C}$ et al (2006) Multidetector CT with double arterial phase and high-iodineconcentration contrast agent in the detection of hepatocellular carcinoma. Radiol Med 111:181-191

10. Goldberg SN, Grassi CJ, Cardella JF et al (2009) Image-guided tumor ablation: standardization of terminology and reporting criteria. J Vasc Interv Radiol 20 (Suppl 7):S377-S390

11. Bruix J, Sherman M; Practice Guidelines Committee, American Association for the Study of Liver Diseases (2005) Management of hepatocellular carcinoma. Hepatology 42:1208-1236

12. Lencioni R, Cioni D, Crocetti L et al (2005) Early-stage hepatocellular carcinoma in patients with cirrhosis: long-term results of percutaneous image-guided radiofrequency ablation. Radiology 234:961-967

13. Park Y, Choi D, Lim HK et al (2008) Growth rate of new hepatocellular carcinoma after percutaneous radiofrequency ablation: evaluation with multiphase CT. AJR Am J Roentgenol 191:215-220

14. Kim YS, Rhim H, Cho OK et al (2006) Intrahepatic recurrence after percutaneous radiofrequency ablation of hepatocellular carcinoma: analysis of the pattern and risk factors. Eur $\mathbf{J}$ Radiol 59:432-441
15. Yamanaka Y, Shiraki K, Miyashita $\mathrm{K}$ et al (2005) Risk factors for the recurrence of hepatocellular carcinoma after radiofrequency ablation of hepatocellular carcinoma in patients with hepatitis C. World J Gastroenterol 11:2174-2178

16. Bartolotta TV, Taibbi A, Midiri M, De Maria M (2008) Hepatocellular cancer response to radiofrequency tumor ablation: contrast-enhanced ultrasound. Abdom Imaging 33:501-511

17. Bartolotta TV, Taibbi A, Midiri M et al (2010) Characterisation of focal liver lesions undetermined at grey-scale US: contrast-enhanced US versus 64-row MDCT and MRI with liver-specific contrast agent. Radiol Med 115:714731

18. Zytoon AA, Ishii H, Murakami K et al (2007) Recurrence-free survival after radiofrequency ablation of hepatocellular carcinoma. A registry report of the impact of risk factors on outcome. Jpn J Clin Oncol 37:658-672

19. Livraghi T (2010) Single HCC smaller than $2 \mathrm{~cm}$ : surgery or ablation: interventional oncologist's perspective. J Hepatobiliary Pancreat Sci 17:425429

20 Lim HK, Choi D, Lee WJ et al (2001) Hepatocellular carcinoma treated with percutaneous radio-frequency ablation: evaluation with follow-up multiphase helical CT. Radiology 221:447-454

21. Nakazawa T, Kokubu S, Shibuya A et al (2007) Radiofrequency ablation of hepatocellular carcinoma: correlation between local tumor progression after ablation and ablative margin. AJR Am J Roentgenol 188:480-488 